contact with the whites and they had not had sufficient time to re-adapt themselves. It is likely that in pre-white times they might have weathered these droughts as they were of comparatively short duration, although severe.

The author came to the conclusion that it is unlikely that any major climatic change has taken place in the central great plains within the last thousand years, and that alternate settlement and abandonment of this area was as true of primitive man as it is of white man's tenure when large-scale government aid has not come to his rescue.

\section{EARTHQUAKE ORIGINS IN THE NEW ZEALAND REGION}

$\mathrm{R}$ C. HAYES, acting director of the Dominion Observatory, Wellington, New Zealand, has been investigating the origins of earthquakes in New Zealand ("Earthquake Origins in the New Zealand Region". Dominion Observatory Bulletin No. S.62). Using new material and improved methods, Hayes has redetermined the epicentres and depths of focus of several earthquakes in the New Zealand region for the years 1931 and 1936-40 inclusive, and has prepared a map showing these epicentres.

From these results it is evident that while the general distribution of earthquake epicentres does not differ appreciably from that indicated in earlier years, the more recent results bring out certain features which were not evident before. For example, the extensive seismic region, covering the eastern and southern parts of the North Island, Cook Strait area, and the northerm part of the South Island is seen to have a sharply defined boundary on its north-west side, concave towards the north-west. It crosses the North Island from the Bay of Plenty to the region north of Cape Farewell, and there are very few earthquakes to the north-west of this line. Deep focus earthquakes may be significant.

Many of the shocks originating in the Gisborne East Cape region and farther eastward have focal depths greater than normal. Origins at depths of $60 \mathrm{~km}$. or more are common in the northern Hawke's Bay and Gisborne regions, the depths tending to increase up to about $100 \mathrm{~km}$. for the submarine shocks farther eastward. Shocks originating in the south-west of South Island also have depths of focus of nearly $100 \mathrm{~km}$. An isolated origin deeper than normal has been located near the north-eastern extremity of South Island $(80 \mathrm{~km}$.).

There is another zone, marked by origins at depths ranging up to $300 \mathrm{~km}$. or more, which extends from near White Island in the Bay of Plenty to the region of Lake Taupo, a zone corresponding very closely with that in which volcanic activity occurs. The greatest depth of origin so far recorded in this zone is $320 \mathrm{~km}$. (nearly 200 miles).

An important feature regarding the distribution of deep shocks which is indicated by the present results is their location with respect to the normal shocks in their vicinity. In most regions around the Pacific, deep-focus shocks tend to congregate away from the Pacific, the normal shocks being located on the Pacific side of them. This is clearly the case in the North Island of New Zealand, where the deep-focus zone has an extensive region of shallower or normal shocks to eastward of it.

\section{FORTHCOMING EVENTS}

(Meeting marked with an asterisk is open to the public.)

\section{Monday, February 2}

ROTAL Society of ARTS (at John Adam Street, Adelphi, London, W.C.2), at 1.45 p.m.-Dr. B. A. Keen, F.R.S. : "Soil Physics, Theory and Practice" (Cantor Lectures, III). ROYAL GEOGRAPHICAL SocIETY (at Kengington Gore, London,
s.W.7), at 3 p.m.-Dr. G. H. C. Hart: "Recent Development in the Netherlands Indies".

\section{Wednesday, February 4}

Royal Soolety of ARTs (at John Adam Street, Adelphi, London, W.C.2), at 1.45 p.m.-Mr. H. G. Jenkins : "Fluorescent Lighting".

\section{Thursday, February 5}

Royal INstitution (at 21 Albemarle Street, London, W.1), at culture"." - Prof. A. W. Ashby: "The Rise of Efficiency in Agri-

\section{APPOINTMENTS VACANT}

ApPLICATIONs are invited for the following appointments on or efore the dates mentioned

Distribution ENGINEER to the Tees Valley Water Board-The Engineer and General Manager, Water Board Offices, Corporation Road, Middlesbrough (February 5).

Chief Electrical Engineer and Manager of the Accrington Electricity Undertaking-The Town Clerk, Town Hall, Accrington (February 9).

Secretary-Steward IN ThF Department OF Pathologr aNd BAcTparology-The Secretary, Welsh National School of Medicine, 10 The Parade, Cardiff (February 10).

HEADMASTER of the King Edward VII School for Boys, Lytham-Messrs. Wilson, Wright and Wilsons, Clerks to the Governors, 6 Chapel Street, Preston, Lancs. (February 13).

MAN OR WOMAN TO TEACH MatheMatros AND MEOHANIOAL DRAWING-The Principal and Organizer of Further Education in Rugby, 61 Clifton Road, Rugby.

ASSISTANT MASTRR in the Technical School of the Royal Aircraft Establishment to teach Mathematics, Mechanics and Machine Drawing-The Central Register (ONC 745), Queen Anne's Chambers, London, S.W.1.

\section{REPORTS and other PUBLICATIONS}

\author{
(not included in the monthly Books Supplement)
}

\section{Great Britain and Ireland}

Scientiflc Proceedings of the Royal Dublin Society. Vol. 22 (N.S.) No. 46: A Strain of the Tuber Blotch Virus causing Top Necrosis in No, 46: A Strain of the Tuber Blotch virus causing Top Necrosis in Hodges, Figgis and Co., Ltd. ; London: Williams and Norgate, Ltd.) Hodges, Figgis and Co., Ltd. ; London: Williams and Norgate, Ltd.] 18. 6a. Brish Chemical Plant. 1941 Official Directory. Pp. 190. (London: British Chemical Plant Manufacturers' Association.) Gratis. [91 A Twentieth Century Economic System. Pp. 60. (London Economic Reform Club.) $6 d$. Tin Research Institute. Publication No. 107: Hot-tinning 'Difficult' Mild Steels. By W. E. Hoare and H. Plummer. Pp. 28. (Green-
ford : Tin Research Institute.) Free.

\section{Other Countries}

Smithsonian Institution : United States National Museum. Bulletin 50: The Birds of North and Middle America : a Descriptive Catalog of the Higher Groups, Genera, Species and Subspecies of Birds known to occur in North America, from the Arctic Lands to the Isthmus of Panama, the West Indies and other Islands of the Caribbean Sea, and the Galapagos Archipelago. By Robert Ridgway, continued by Herbert Friedmann. Part 9: Family Gruidae-The Cranes; Family Rallidae -The Rails, Coots and Gallinules; Family Heliornithidae-The Sungrebes; Family Eurypygidae-The Sun-bitterns. Pp. ix +254 . (Washington, D.C. : Government Printing Office.) 40 cents. [11 Smithsonian Institution: Bureau of American Ethnology. Bulletin 131: Peachtree Mound and Village Site, Cherokee County, North Carolina. By Frank M. Setzler and Jesse D. Jennings ; with Appendix Skeletal Remains from the Peachtree Site, North Carolina, by T. D Stewart. Pp. ix $+103+50$ plates. (Washington, D.C.: Government Printing office.) 40 cents.

U.S. Department of Agriculture. Farmers* Bulletin No. 1884 : U.S. Department of Agriculture. Farmers Bulletin No. 1884 : The Sugar-cane Borer. By J. W. Ingram and E. K. Bynum. Pp. ii +17. 5 cents. Technical Bulletin No. 783 : Selenium Occurrence in Certain Soils in the United States, with a Discussion of Related Topics : Sixth Report. By H. W. Lakin and H. G. Byers. Pp. 27. 5 cents. (Washing.
ton, D.C.: Government Printing Office.) 